\title{
Chapter 4 \\ Breast Cancer Risk and Mortality in Women of Latin American Origin
}

\author{
Laura Fejerman, Silvia J. Serrano-Gómez, and Lizeth I. Tamayo
}

\section{Introduction}

The categories of Hispanic or Latino refer to individuals of diverse national origin (Mexico and all countries in the Caribbean, Central and South America), place of birth (individuals born in the United States whose ancestors were born in Latin America or individuals born in Latin America), and continental ancestral backgrounds (mostly European, Indigenous American (IA), and African, but also including Asian and other minor components). This diversity had not been systematically addressed in cancer epidemiology until recent years, and the lack of extensive datasets with detailed information about subgroups of Latinos has resulted in the placing of a very diverse set of individuals into one category. This is surprising given that Hispanics/Latinos represent the second largest US census racial/ethnic category including $\sim 17 \%$ of the US population (50 million individuals) [1].

Breast cancer is the most common cancer in US Latinas [2], but compared to other population groups, incidence is relatively low. Age-adjusted breast cancer incidence rates based on 2010-2014 cases were 127.7 in non-Latina Whites (NLWs), 125.1 in non-Latina Blacks (NLBs), 98.5 in Asians/Pacific Islanders, 93.1 in Latinas,

Silvia J. Serrano-Gómez and Lizeth I. Tamayo contributed equally to the content of the manuscript.

\footnotetext{
L. Fejerman $(\bowtie)$

Division of General Internal Medicine, Department of Medicine, Institute of Human Genetics and Helen Diller Family Comprehensive Cancer Center, University of California San Francisco, San Francisco, CA, USA e-mail: Laura.fejerman@ucsf.edu

S. J. Serrano-Gómez

Grupo de investigación en biología del cáncer, Instituto Nacional de Cancerología, Bogotá, DC, Colombia

L. I. Tamayo

Department of Public Health Sciences, The University of Chicago, Chicago, IL, USA
} 
and 82.2 in Native Americans/Alaskan Natives [3]. Some studies have shown that despite the lower incidence of breast cancer in Latinas, their mortality risk is higher than NLW women, even after adjustment for tumor characteristics and socioeconomic status [4-8]. However, this observation is not consistent across studies, with several reporting lower risk of breast cancer-specific mortality for Latinas compared to other population groups [9-12]. In addition, Latinas have been reported to have a higher risk of developing aggressive subtypes [13] and of being diagnosed at more advanced stages of the disease [12,14].

This chapter summarizes works conducted by our group and others on breast cancer risk, characteristics, and survival, in women of Latin American origin, with particular emphasis on observed differences among Latino subgroups.

\section{Breast Cancer Risk in Women of Latin American Origin}

The group usually designated by the category of Hispanics/Latinos is not homogeneous, and the risk of developing breast cancer among these women varies by national origin [15], place of birth (US-born vs. foreign-born) [16, 17], and genetic ancestry $[18,19]$.

A study that was based on cancer registry data from Florida, including diagnosis between the years 1999 and 2001 and $~ 30,000$ Latinas, reported overall age-adjusted incidence rates of 106.4 (100.8-112.3) in this group, 140.4 (137.6-143.2) in NLWs, and 104.9 (98.5-111.7) in NLBs. Incidence rates varied greatly among Latinas by national origin, with Puerto Ricans having the highest rates (116.9; 103.7-131.4), followed by Cubans (108.0; 96.7-120.3) and Mexicans (71.9; 53.1-95.2). The incidence of breast cancer in Caribbean women was markedly higher than that in AAs [15]. The 2000 and 2005 National Health Interview Survey (NHIS) Cancer Control Modules observed a higher 5-year absolute risk in Cubans/Cuban-Americans compared to Mexican/Mexican-Americans and a higher lifetime risk in Dominicans compared to Mexican/Mexican-Americans [20].

Studies have reported that foreign-born Latinas have lower breast cancer incidence than their US-born counterpart [16, 17]. In California, foreign-born Latinas have lower risk of developing breast cancer than US-born [17], with increasing risk with longer US residency [16]. The study based on the Florida Cancer Registry also reported marked differences in incidence between Latinas residing in the United States and those in their countries of origin. Breast cancer incidence rates were reported to be twice or even three times higher in US women of Latin American origin, as in the case of Cubans (31 per 100,000 in Cuba vs. 78 in Florida) [15]. Concordant with these results, a study that compared cancer incidence between Puerto Ricans in the United States and in those residing in the Island found a significantly lower breast cancer incidence among Puerto Rican women who reside in Puerto Rico [21]. Differences in risk of breast cancer by place of birth could be explained by lifestyle changes related to the adoption of a more westernized reproductive behavior (i.e., lower parity, shorter duration of breast-feeding, and later age 
at first full-term pregnancy) and dietary or other lifestyle choices (i.e., more fast food, higher alcohol intake, less exercise) [16, 22].

Genetic ancestry also varies among Latinas, and it has been reported that women with high IA ancestry have lower risk of developing breast cancer than those with high European ancestry. This difference was statistically significant after controlling for most established risk factors that are known to differ between Latina and NLW women $[18,19]$. The inverse association between IA ancestry and breast cancer risk was partly explained by a genetic variant located near the estrogen receptor 1 gene (ESR1), shown to be of relatively high frequency in women with IA ancestry [23]. In Colombia, patients diagnosed with estrogen receptor-negative breast cancer (HER2-enriched, basal-like, and non-basal triple negative) had the highest African ancestry [24]; however, the role of African ancestry in defining breast cancer risk by Latina national origin has not been fully examined.

\section{Breast Cancer Mortality in Women of Latin American Origin}

The described heterogeneity among Latinas not only translates into differences in breast cancer risk but also mortality. Cubans and Puerto Ricans have the highest mortality rates [25], while Mexicans, Central Americans, South Americans, and Dominicans have lower breast cancer mortality rates [25].

Few studies have analyzed differences in cancer mortality by genetic ancestry in women of Latin American origin. In 2013, Fejerman et al. analyzed the association between genetic ancestry and survival in Latina women from the San Francisco Bay area and reported higher mortality hazard in women with more than $50 \%$ of IA ancestry compared to women with $50 \%$ or less of IA ancestry [26]. Nevertheless, when the association was re-tested in women with uniform access to healthcare, the previously observed disparity in breast cancer-specific mortality was no longer apparent [27].

Ellis et al. showed that stage at diagnosis explained $11 \%$ of the survival disparities in Latina women compared to NLW women [28]. Socioeconomic status is an important contributor to health disparities in breast cancer outcomes as reduced screening, diagnostic delays and barriers to comprehensive treatment can lead to later stage at diagnosis [29]. Latina women are less likely to use mammography screening compared to NLW women [29-31]. In addition, delays in the diagnostic biopsy after an abnormal screening study might contribute to the more advanced stages at presentation [29] and delays in treatment initiation [12]. Results of a study based in Chicago showed an inverse association between European genetic ancestry and the risk of late stage at diagnosis (OR 0.70, 95\% CI: 0.54-0.92) among Latina patients even after adjusting for multiple social and behavioral risk factors [32].

While breast cancer incidence is relatively low in foreign-born Latinas, they are more likely to be diagnosed with breast cancer at more advanced stages, initiate treatment later, and are less likely to receive guidelines-concordant treatment when compared to US-born Latinas [17]. Some studies have reported that even though 
foreign-born Latinas are more likely to be diagnosed with more advanced stages, they have better survival than US-born Latinas [17, 33, 34]. This is a well-known phenomenon called the immigrant paradox that refers to the better health outcomes observed for certain immigrant populations in the United States compared to nonimmigrant individuals of similar socioeconomic background [35]. The fact that Latina women experience survival advantages can be related in part to the lifestyles adopted in Latino enclaves, in which they may promote better health attitudes and behaviors such as healthier diets and social support $[17,34,36]$. These enclaves are neighborhoods with dense US-born Latino or Latino immigrant populations that hold certain cultural norms and practices [33,35]. It is important to mention that the better survival of foreign-born Latinas could be partly an artifact related to the return of these women to their native countries leading to an under-ascertainment of deaths $[33,36]$.

\section{Breast Tumor Subtypes in Women of Latin American Origin}

Breast cancer is a complex and heterogeneous disease that has been classified into four main intrinsic subtypes based on gene expression profiles: luminal A, luminal B, HER2-enriched, and basal-like [37, 38]. Luminal subtypes belong to the estrogen receptor-positive (ER+) group and are characterized by the expression of genes such as the estrogen receptor gene (ESR1) and genes regulated by estrogen such as GATA3 [39]. Although globally, luminal subtypes show the best outcomes, luminal B have a more aggressive phenotype as they express higher levels of proliferationrelated genes and growth factor receptors such as HER2 [40, 41]. HER2-enriched and basal-like subtypes are ER-negative (ER-) subtypes. HER2-enriched tumors express ERBB2 and genes in the 17q22.24 locus [39, 42, 43] while basal-like subtype express basement membrane cytokeratins and lack the expression of ESR1 and its co-expressed genes [39]. ER- subtypes have the poorest prognosis when compared to luminal subtypes [44].

The distribution of breast cancer intrinsic subtypes varies among women from different populations, and Latina women have a higher proportion of more aggressive intrinsic subtypes such as ER- tumors than NLW women [13]. This is very important as these subtypes of disease have fewer treatment options and a poorer prognosis than other subtypes [3, 6, 45-48].

This differential distribution of subtypes in Latina compared to NLW women has been shown not only in population-based studies but also in hospital/clinical-based studies in Latin America. In population-based studies from the United States [4960], the proportion of the triple-negative subtype in Latinas ranged between 10 and $18 \%$, while in NLW women, it ranged between 8 and $15 \%$. On the other hand, HERenriched tumors ranged between 4 and 24\% in Latinas and between 3 and 17\% in NLW women. Not only US Latinas, but also Latin American women more generally, have a $20-40 \%$ higher risk of developing ER-/PR - and triple-negative breast cancers (TNBC) than NLW women [19, 54, 61-67]. 
Most studies performed in Latin America are hospital-based [24, 65, 68-73]. The reported proportion of triple-negative subtype in Latin America ranged between 12 and 24\% and between 7 and 24\% for the HER2-enriched subtype [47] (Fig. 4.1). Countries such as Mexico [47], Peru, and Colombia have higher relative frequency of triple-negative tumors $(23 \%, 21 \%$, and $21 \%$, respectively) compared to other countries in Latin America such as Costa Rica (17\%) [69], Brazil (17\%) [65], and Puerto Rico (17\%) [70]. When comparing hospital-based studies with those performed at national referral centers such as the National Cancer Institutes from each country, differences are also observed. For example, a hospital-based study in Peru reported that the proportion of triple-negative breast cancer was $17 \%$ [73] while in the study from The National Cancer Institute from Peru, it was 23\% [71]. A similar scenario was observed in Colombia where a hospital-based study reported a proportion of $12 \%$ [72], while the Colombian National Cancer Institute reported a proportion of 21\% [24] (Fig. 4.1). More studies are needed to decipher the distribution of intrinsic subtypes in a population-based scenario in Latin America and also to analyze the relationship between genetic ancestry tumor subtype.

The heterogeneity in the distribution of breast cancer subtypes in women of Latin American origin can be partly attributed to the differences in the source of

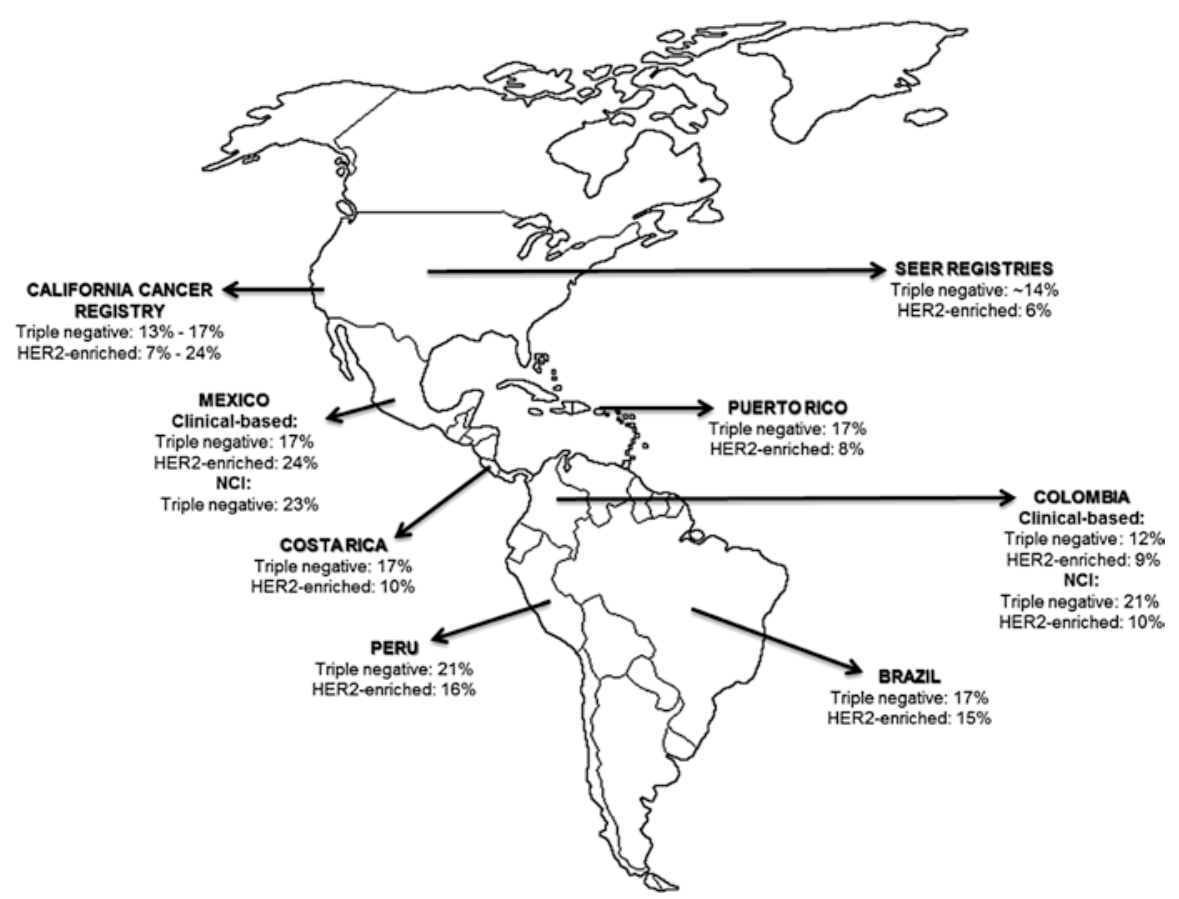

Fig. 4.1 Prevalence of triple-negative and HER2-enriched breast cancers in women of Latin American origin. Differences in the prevalence of these subtypes are noted between the different Latin American countries and also within the same country according to the source used, hospitalbased, or reference center 
information. National Cancer Institutes in Latin America are usually reference centers that receive patients that could not be adequately served by local hospitals/ clinics, likely because of their advanced stage at diagnosis and tumor aggressiveness. Additionally, differences could result from the surrogates used to classify breast cancer into intrinsic subtypes (PAM50 or St. Gallen surrogates), although most studies used the basic classification that includes the evaluation of ER, PR, and HER2 [13].

Recent studies suggested that genetic ancestry could be acting as a modulator of gene expression and a risk modifier for the development of specific subtypes of breast cancer in Latina women [74]. Serrano-Gómez et al. reported that Colombian breast cancer patients with higher IA ancestry showed higher expression of the ERBB2/GRB7/MIEN1 genes in breast tumors of luminal B subtype [74]. These three genes, located in the same region of chromosome 17, have been reported as co-amplified in breast cancer and this event has been associated with poor prognosis $[42,75-77]$.

\section{Gaps: Do We Have the Right Data to Learn to Predict, Prevent, and Treat Breast Cancer in Women of Latin American Origin?}

Genomic technologies have offered new perspectives to expand and improve human health [78]. However, it has been shown that the proportion of samples from minority populations included in large-scale genomic studies remains low [79, 80]. Individuals of Latin American origin only represent $0.54 \%$ of the samples included in genome-wide association analyses compared to $81 \%$ for those of European ancestry [80]. A similar scenario was observed in The Cancer Genome Atlas (TCGA) where only $3 \%$ of the samples are from Latino patients [79]. Increasing the representation of diverse populations in future "omics" research efforts will improve our understanding of the drivers of aggressive tumor biology across different population groups and subgroups [79].

The need for cancer control in Latin America has received significant attention, with specific recommendations to increase investment in cancer registration, given that cancer registration covers approximately $7 \%$ of the populations in Latin America, while the equivalent coverage is $83 \%$ in North America and $32 \%$ in Europe $[78,81]$.

To assure comprehensive registries, the implementation of population-based cancer registries (PBCR) in Latin America require government support in order to incorporate all sources of information such as data from social security and the private sector [82, 83]. Biorepositories in Latin America hold diverse tissue samples that could enrich our knowledge of the molecular diversity of cancer in Latinos from different regions, but they tend to lack the resources to conduct the research. Therefore, it is through international collaborations, including support from US 
institutions and investigators, that we can begin to generate the complex data that we need to better understand cancer risk and outcomes with the consideration of biological, environmental, cultural, and access-related factors in individuals of Latin American origin.

\section{References}

1. Colby SL, Ortman J. Projections of the size and composition of the US population: 2014 to 2060. Current population reports, P25-1143. Washington, DC: U.S. Census Bureau; 2014.

2. Siegel RL, Fedewa SA, Miller KD, Goding-Sauer A, Pinheiro PS, Martinez-Tyson D, et al. Cancer statistics for Hispanics/Latinos, 2015. CA Cancer J Clin. 2015;65(6):457-80.

3. SEER: Surveillance, Epidemiology, and End Results (SEER) Program (www.seer.cancer.gov) SEER $*$ Stat Database. 2016. https://seer.cancer.gov/statfacts/html/breast.html.

4. DeSantis CE, Ma J, Goding Sauer A, Newman LA, Jemal A. Breast cancer statistics, 2017, racial disparity in mortality by state. CA Cancer J Clin. 2017;67(6):439-48.

5. Yedjou CG, Tchounwou PB, Payton M, Miele L, Fonseca DD, Lowe L, et al. Assessing the racial and ethnic disparities in breast cancer mortality in the United States. Int J Environ Res Public Health. 2017;14(5).

6. Ooi SL, Martinez ME, Li CI. Disparities in breast cancer characteristics and outcomes by race/ ethnicity. Breast Cancer Res Treat. 2011;127(3):729-38.

7. Iqbal J, Ginsburg O, Rochon PA, Sun P, Narod SA. Differences in breast cancer stage at diagnosis and cancer-specific survival by race and ethnicity in the United States. JAMA. 2015;313(2):165-73.

8. Hill DA, Nibbe A, Royce ME, Wallace AM, Kang H, Wiggins CL, et al. Method of detection and breast cancer survival disparities in Hispanic women. Cancer Epidemiol Biomarkers Prev. 2010;19(10):2453-60.

9. Wu AH, Gomez SL, Vigen C, Kwan ML, Keegan TH, Lu Y, et al. The California Breast Cancer Survivorship Consortium (CBCSC): prognostic factors associated with racial/ethnic differences in breast cancer survival. Cancer Causes Control. 2013;24(10):1821-36.

10. Tannenbaum SL, Koru-Sengul T, Miao F, Byrne MM. Disparities in survival after female breast cancer diagnosis: a population-based study. Cancer Causes Control. 2013;24(9):1705-15.

11. Curtis E, Quale C, Haggstrom D, Smith-Bindman R. Racial and ethnic differences in breast cancer survival: how much is explained by screening, tumor severity, biology, treatment, comorbidities, and demographics? Cancer. 2008;112(1):171-80.

12. Maskarinec G, Sen C, Koga K, Conroy SM. Ethnic differences in breast cancer survival: status and determinants. Womens Health (Lond). 2011;7(6):677-87.

13. Serrano-Gomez SJ, Fejerman L, Zabaleta J. Breast cancer in Latinas: a focus on intrinsic subtypes distribution. Cancer Epidemiol Biomarkers Prev. 2018;27(1):3-10.

14. Parise CA, Caggiano V. The influence of socioeconomic status on racial/ethnic disparities among the ER/PR/HER2 breast cancer subtypes. J Cancer Epidemiol. 2015;2015:813456.

15. Pinheiro PS, Sherman RL, Trapido EJ, Fleming LE, Huang Y, Gomez-Marin O, et al. Cancer incidence in first generation U.S. Hispanics: Cubans, Mexicans, Puerto Ricans, and new Latinos. Cancer Epidemiol Biomarkers Prev. 2009;18(8):2162-9.

16. John EM, Phipps AI, Davis A, Koo J. Migration history, acculturation, and breast cancer risk in Hispanic women. Cancer Epidemiol Biomarkers Prev. 2005;14(12):2905-13.

17. Keegan TH, John EM, Fish KM, Alfaro-Velcamp T, Clarke CA, Gomez SL. Breast cancer incidence patterns among California Hispanic women: differences by nativity and residence in an enclave. Cancer Epidemiol Biomarkers Prev. 2010;19(5):1208-18.

18. Fejerman L, Romieu I, John EM, Lazcano-Ponce E, Huntsman S, Beckman KB, et al. European ancestry is positively associated with breast cancer risk in Mexican women. Cancer Epidemiol Biomarkers Prev. 2010;19(4):1074-82. 
19. Fejerman L, John EM, Huntsman S, Beckman K, Choudhry S, Perez-Stable E, et al. Genetic ancestry and risk of breast cancer among U.S. Latinas. Cancer Res. 2008;68(23):9723-8.

20. Banegas MP, Leng M, Graubard BI, Morales LS. The risk of developing invasive breast cancer in Hispanic women: a look across Hispanic subgroups. Cancer. 2013;119(7):1373-80.

21. Bild AH, Parker JS, Gustafson AM, Acharya CR, Hoadley KA, Anders C, et al. An integration of complementary strategies for gene-expression analysis to reveal novel therapeutic opportunities for breast cancer. Breast Cancer Res. 2009;11(4):R55.

22. Andreeva VA, Unger JB, Pentz MA. Breast cancer among immigrants: a systematic review and new research directions. J Immigr Minor Health. 2007;9(4):307-22.

23. Fejerman L, Ahmadiyeh N, Hu D, Huntsman S, Beckman KB, Caswell JL, et al. Genome-wide association study of breast cancer in Latinas identifies novel protective variants on 6q25. Nat Commun. 2014;5:5260.

24. Serrano-Gomez SJ, Sanabria-Salas MC, Hernandez-Suarez G, Garcia O, Silva C, Romero A, et al. High prevalence of luminal B breast cancer intrinsic subtype in Colombian women. Carcinogenesis. 2016;37(7):669-76.

25. Pinheiro PS, Callahan KE, Siegel RL, Jin H, Morris CR, Trapido EJ, et al. Cancer mortality in Hispanic ethnic groups. Cancer Epidemiol Biomarkers Prev. 2017;26(3):376-82.

26. Fejerman L, Hu D, Huntsman S, John EM, Stern MC, Haiman CA, et al. Genetic ancestry and risk of mortality among U.S. Latinas with breast cancer. Cancer Res. 2013;73(24):7243-53.

27. Engmann NJ, Ergas IJ, Yao S, Kwan ML, Roh JM, Ambrosone CB, et al. Genetic ancestry is not associated with breast cancer recurrence or survival in U.S. Latina women enrolled in the Kaiser Permanente Pathways Study. Cancer Epidemiol Biomarkers Prev. 2017;26(9):1466-9.

28. Ellis L, Canchola AJ, Spiegel D, Ladabaum U, Haile R, Gomez SL. Racial and ethnic disparities in cancer survival: the contribution of tumor, sociodemographic, institutional, and neighborhood characteristics. J Clin Oncol. 2018;36(1):25-33.

29. Newman LA. Breast cancer disparities: socioeconomic factors versus biology. Ann Surg Oncol. 2017;24(10):2869-75.

30. Yanez B, McGinty HL, Buitrago D, Ramirez AG, Penedo FJ. Cancer outcomes in Hispanics/ Latinos in the United States: an integrative review and conceptual model of determinants of health. J Lat Psychol. 2016;4(2):114-29.

31. Smith-Gagen J, Carrillo JE, Ang A, Pérez-Stable EJ. Practices that reduce the Latina survival disparity after breast cancer. J Womens Health (Larchmt). 2013;22(11):938-46.

32. Al-Alem U, Rauscher G, Shah E, Batai K, Mahmoud A, Beisner E, et al. Association of genetic ancestry with breast cancer in ethnically diverse women from Chicago. PLoS One. 2014;9(11):e112916.

33. Keegan TH, Quach T, Shema S, Glaser SL, Gomez SL. The influence of nativity and neighborhoods on breast cancer stage at diagnosis and survival among California Hispanic women. BMC Cancer. 2010;10:603.

34. Pruitt SL, Tiro JA, Xuan L, Lee SJ. Hispanic and immigrant paradoxes in U.S. breast cancer mortality: impact of neighborhood poverty and Hispanic density. Int J Environ Res Public Health. 2016;13(12).

35. Patel MI, Schupp CW, Gomez SL, Chang ET, Wakelee HA. How do social factors explain outcomes in non-small-cell lung cancer among Hispanics in California? Explaining the Hispanic paradox. J Clin Oncol. 2013;31(28):3572-8.

36. Ruiz JM, Steffen P, Smith TB. Hispanic mortality paradox: a systematic review and metaanalysis of the longitudinal literature. Am J Public Health. 2013;103(3):e52-60.

37. Perou CM, Sørlie T, Eisen MB, Van de Rijn M, Jeffrey SS, Rees CA, et al. Molecular portraits of human breast tumours. Nature. 2000;406(6797):747-52.

38. Parker JS, Mullins M, Cheang MC, Leung S, Voduc D, Vickery T, et al. Supervised risk predictor of breast cancer based on intrinsic subtypes. J Clin Oncol. 2009;27(8):1160-7.

39. Cancer Genome Atlas N. Comprehensive molecular portraits of human breast tumours. Nature. 2012;490(7418):61-70.

40. Creighton CJ. The molecular profile of luminal B breast cancer. Biologics. 2012;6:289-97. 
41. Cheang MC, Chia SK, Voduc D, Gao D, Leung S, Snider J, et al. Ki67 index, HER2 status, and prognosis of patients with luminal B breast cancer. J Natl Cancer Inst. 2009;101(10):736-50.

42. Nadler Y, Gonzalez AM, Camp RL, Rimm DL, Kluger HM, Kluger Y. Growth factor receptorbound protein-7 (Grb7) as a prognostic marker and therapeutic target in breast cancer. Ann Oncol. 2010;21(3):466-73.

43. Pradip D, Bouzyk M, Dey N, Leyland-Jones B. Dissecting GRB7-mediated signals for proliferation and migration in HER2 overexpressing breast tumor cells: GTP-ase rules. Am J Cancer Res. 2013;3(2):173-95.

44. Sorlie T, Perou CM, Tibshirani R, Aas T, Geisler S, Johnsen H, et al. Gene expression patterns of breast carcinomas distinguish tumor subclasses with clinical implications. Proc Natl Acad Sci U S A. 2001;98(19):10869-74.

45. Lynce F, Graves KD, Jandorf L, Ricker C, Castro E, Moreno L, et al. Genomic disparities in breast cancer among Latinas. Cancer Control. 2016;23(4):359-72.

46. Boyle T, McPadden E. Breast cancer presents at an earlier age in Mexican American women. Breast J. 2004;10(5):462-4.

47. Lara-Medina F, Perez-Sanchez V, Saavedra-Perez D, Blake-Cerda M, Arce C, MotolaKuba D, et al. Triple-negative breast cancer in Hispanic patients: high prevalence, poor prognosis, and association with menopausal status, body mass index, and parity. Cancer. 2011;117(16):3658-69.

48. Parise CA, Bauer KR, Brown MM, Caggiano V. Breast cancer subtypes as defined by the estrogen receptor (ER), progesterone receptor (PR), and the human epidermal growth factor receptor 2 (HER2) among women with invasive breast cancer in California, 1999-2004. Breast J. 2009;15(6):593-602.

49. Kwan ML, John EM, Caan BJ, Lee VS, Bernstein L, Cheng I, et al. Obesity and mortality after breast cancer by race/ethnicity: the California Breast Cancer Survivorship Consortium. Am J Epidemiol. 2014;179(1):95-111.

50. Kurian AW, Fish K, Shema SJ, Clarke CA. Lifetime risks of specific breast cancer subtypes among women in four racial/ethnic groups. Breast Cancer Res. 2010;12(6):R99.

51. Clarke CA, Keegan TH, Yang J, Press DJ, Kurian AW, Patel AH, et al. Age-specific incidence of breast cancer subtypes: understanding the black-white crossover. J Natl Cancer Inst. 2012;104(14):1094-101.

52. Howlader N, Altekruse SF, Li CI, Chen VW, Clarke CA, Ries LA, et al. US incidence of breast cancer subtypes defined by joint hormone receptor and HER2 status. J Natl Cancer Inst. 2014;106(5).

53. Chen L, Li CI. Racial disparities in breast cancer diagnosis and treatment by hormone receptor and HER2 status. Cancer Epidemiol Biomarkers Prev. 2015;24(11):1666-72.

54. Banegas MP, Tao L, Altekruse S, Anderson WF, John EM, Clarke CA, et al. Heterogeneity of breast cancer subtypes and survival among Hispanic women with invasive breast cancer in California. Breast Cancer Res Treat. 2014;144(3):625-34.

55. Hines LM, Risendal B, Byers T, Mengshol S, Lowery J, Singh M. Ethnic disparities in breast tumor phenotypic subtypes in Hispanic and non-Hispanic white women. J Womens Health (Larchmt). 2011;20(10):1543-50.

56. Hines LM, Risendal B, Slattery ML, Baumgartner KB, Giuliano AR, Byers T. Differences in estrogen receptor subtype according to family history of breast cancer among Hispanic, but not non-Hispanic White women. Cancer Epidemiol Biomarkers Prev. 2008;17(10):2700-6.

57. Kroenke CH, Sweeney C, Kwan ML, Quesenberry CP, Weltzien EK, Habel LA, et al. Race and breast cancer survival by intrinsic subtype based on PAM50 gene expression. Breast Cancer Res Treat. 2014;144(3):689-99.

58. Sweeney C, Bernard PS, Factor RE, Kwan ML, Habel LA, Quesenberry CP Jr, et al. Intrinsic subtypes from PAM50 gene expression assay in a population-based breast cancer cohort: differences by age, race, and tumor characteristics. Cancer Epidemiol Biomarkers Prev. 2014;23(5):714-24. 
59. Sineshaw HM, Gaudet M, Ward EM, Flanders WD, Desantis C, Lin CC, et al. Association of race/ethnicity, socioeconomic status, and breast cancer subtypes in the National Cancer Data Base (2010-2011). Breast Cancer Res Treat. 2014;145(3):753-63.

60. Plasilova ML, Hayse B, Killelea BK, Horowitz NR, Chagpar AB, Lannin DR. Features of triple-negative breast cancer: analysis of 38,813 cases from the national cancer database. Medicine (Baltimore). 2016;95(35):e4614.

61. Carey LA, Perou CM, Livasy CA, Dressler LG, Cowan D, Conway K, et al. Race, breast cancer subtypes, and survival in the Carolina Breast Cancer Study. JAMA. 2006;295(21):2492-502.

62. Dunnwald LK, Rossing MA, Li CI. Hormone receptor status, tumor characteristics, and prognosis: a prospective cohort of breast cancer patients. Breast Cancer Res. 2007;9(1):R6.

63. Banegas MP, Li CI. Breast cancer characteristics and outcomes among Hispanic black and Hispanic white women. Breast Cancer Res Treat. 2012;134(3):1297-304.

64. Newman LA, Griffith KA, Jatoi I, Simon MS, Crowe JP, Colditz GA. Meta-analysis of survival in African American and white American patients with breast cancer: ethnicity compared with socioeconomic status. J Clin Oncol. 2006;24(9):1342-9.

65. de Macedo Andrade AC, Ferreira Junior CA, Dantas Guimaraes B, Pessoa Barros AW, Sarmento de Almeida G, Weller M. Molecular breast cancer subtypes and therapies in a public hospital of Northeastern Brazil. BMC Womens Health. 2014;14:110.

66. Sans M. Admixture studies in Latin America: from the 20th to the 21st century. Hum Biol. 2000;72(1):155-77.

67. Gonzalez-Angulo AM, Timms KM, Liu S, Chen H, Litton JK, Potter J, et al. Incidence and outcome of BRCA mutations in unselected patients with triple receptor-negative breast cancer. Clin Cancer Res. 2011;17(5):1082-9.

68. Singh M, Ding Y, Zhang LY, Song D, Gong Y, Adams S, et al. Distinct breast cancer subtypes in women with early-onset disease across races. Am J Cancer Res. 2014;4(4):337-52.

69. Srur-Rivero N, Cartin-Brenes M. Breast cancer characteristics and survival in a Hispanic population of costa rica. Breast Cancer (Auckl). 2014;8:103-8.

70. Ortiz AP, Frias O, Perez J, Cabanillas F, Martinez L, Sanchez C, et al. Breast cancer molecular subtypes and survival in a hospital-based sample in Puerto Rico. Cancer Med. 2013;2(3):343-50.

71. Vallejos CS, Gomez HL, Cruz WR, Pinto JA, Dyer RR, Velarde R, et al. Breast cancer classification according to immunohistochemistry markers: subtypes and association with clinicopathologic variables in a Peruvian hospital database. Clin Breast Cancer. 2010;10(4):294-300.

72. Gomez R, Ossa CA, Montoya ME, Echeverri C, Angel G, Ascuntar J, et al. Impact of immunohistochemistry-based molecular subtype on chemosensitivity and survival in Hispanic breast cancer patients following neoadjuvant chemotherapy. Ecancermedicalscience. 2015;9:562.

73. Martinez ME, Wertheim BC, Natarajan L, Schwab R, Bondy M, Daneri-Navarro A, et al. Reproductive factors, heterogeneity, and breast tumor subtypes in women of Mexican descent. Cancer Epidemiol Biomarkers Prev. 2013;22(10):1853-61.

74. Serrano-Gomez SJ, Sanabria-Salas MC, Garay J, Baddoo MC, Hernandez-Suarez G, Mejia $\mathrm{JC}$, et al. Ancestry as a potential modifier of gene expression in breast tumors from Colombian women. PLoS One. 2017;12(8):e0183179.

75. Vinatzer U, Dampier B, Streubel B, Pacher M, Seewald MJ, Stratowa C, et al. Expression of HER2 and the coamplified genes GRB7 and MLN64 in human breast cancer: quantitative real-time reverse transcription-PCR as a diagnostic alternative to immunohistochemistry and fluorescence in situ hybridization. Clin Cancer Res. 2005;11(23):8348-57.

76. Kpetemey M, Chaudhary P, Van Treuren T, Vishwanatha JK. MIEN1 drives breast tumor cell migration by regulating cytoskeletal-focal adhesion dynamics. Oncotarget. 2016;7(34):54913-24.

77. Kpetemey M, Dasgupta S, Rajendiran S, Das S, Gibbs LD, Shetty P, et al. MIEN1, a novel interactor of Annexin A2, promotes tumor cell migration by enhancing AnxA2 cell surface expression. Mol Cancer. 2015;14:156. 
78. Torres Á, Oliver J, Frecha C, Montealegre AL, Quezada-Urbán R, Díaz-Velásquez CE, et al. Cancer genomic resources and present needs in the Latin American region. Public Health Genomics. 2017;20(3):194-201.

79. Spratt DE, Chan T, Waldron L, Speers C, Feng FY, Ogunwobi OO, et al. Racial/ethnic disparities in genomic sequencing. JAMA Oncol. 2016;2(8):1070-4.

80. Popejoy AB, Fullerton SM. Genomics is failing on diversity. Nature. 2016;538(7624):161-4.

81. Piñeros M, Abriata MG, Mery L, Bray F. Cancer registration for cancer control in Latin America: a status and progress report. Rev Panam Salud Publica. 2017;41:e2.

82. Piñeros M, Znaor A, Mery L, Bray F. A global cancer surveillance framework within noncommunicable disease surveillance: making the case for population-based cancer registries. Epidemiol Rev. 2017;39(1):161-9.

83. Arrossi S. Cancer registration and information systems in Latin America. Lancet Oncol. 2015;16(14):1400-1.

Open Access This chapter is licensed under the terms of the Creative Commons Attribution-NonCommercial 4.0 International License (http://creativecommons.org/licenses/ by-nc/4.0/), which permits any noncommercial use, sharing, adaptation, distribution and reproduction in any medium or format, as long as you give appropriate credit to the original author(s) and the source, provide a link to the Creative Commons license and indicate if changes were made.

The images or other third party material in this chapter are included in the chapter's Creative Commons license, unless indicated otherwise in a credit line to the material. If material is not included in the chapter's Creative Commons license and your intended use is not permitted by statutory regulation or exceeds the permitted use, you will need to obtain permission directly from the copyright holder.

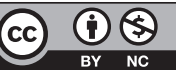

